\title{
Aplikasi Sistem Pakar Penentuan Kesehatan Makanan Khas Sulawesi Utara
}

\author{
Muhammad Iqbal Kaplale,Alicia A. E. Sinsuw, ST, MT, dan Muhamad Dwisnanto Putro, ST,M.Eng. \\ muhammadiqbal.kaplale@yahoo.com, aliciasinsuw@yahoo.com, dwisnantoputro@gmail.com \\ Teknik Informatika, Universitas Sam Ratulangi, Manado, Indonesia.
}

\begin{abstract}
Perkembangan teknologi informasi telah berkembang pesat dalam membantu masalah kesehatan.Penelitian ini adalah untuk mengimplementasikan informasi kesehatan makanan khas Sulawesi Utara ke dalam bentuk Aplikasi sistem pakar berbasis Android. Pengembangan Aplikasi sistem pakar penentu kesehatan makanan khas Sulawesi Utara ini menggunakan metode Backward Chaining. Tujuan pembuatan aplikasi sistem pakar penentu kesehatan makanan khas Sulawesi Utara yaitu membantu pengguna dalam mendapatkan informasi makanan khas Sulawesi Utara.Baik informasi berupa komposisi makanan, informasi nilai gizi dan juga saran kesehatan bagi pengguna. Hasil penelitian dari pembuatan aplikasi sistem pakar penentu kesehatan makanan khas Sulawesi Utara yaitu untuk membantu masyarakat dan Pemerintah Kota Manado dalam mendapatkan informasi makanan khas Sulawesi Utara.
\end{abstract}

Kata Kunci : Makanan Khas Sulawesi Utara, Sistem Pakar, Backward Chaining.

\section{PENDAHULUAN}

Teknologi informasi menjanjikan perkembangan bagi lingkungan kesehatan tetapi tidak sedikit tantangan yang harus dihadapi. Banyak organisasi kesehatan mencoba untuk menggunakan peralatan terbaru tanpa pengetahuan dan prosedur yang memadai serta dasar-dasar yang diperlukan untuk penggunaan yang tepat. Dasar-dasar tersebut meliputi desain ulang proses, peningkatan kinerja, dan manajemen perubahan. Keterbatasan tidak terletak pada teknologi informasi yang digunakan tetapi pengawasan sangat dibutuhkan untuk keberhasilan adopsi teknologi tersebut. [7]

Secara global, layanan kesehatan dianggap industri jasa terbesar yang menjadi prioritas utama serta merupakan investasi yang sangat besar yang tumbuh dengan pesat di sebagian besar negara maju. [7]

Makanan tradisional/khas adalah makanan dan minuman yang biasa dikonsumsi oleh masyarakat tertentu, dengan citarasa khas yang diterima oleh masyarakat tersebut. Bagi masyarakat Indonesia umumnya amat diyakini khasiat, aneka pangan tradisional, seperti tempe, tahu, bawang putih, madu, temulawak, gado-gado, kacang hijau, ikan laut, ikan darat dll. Karena disamping khasiat, makanan tradisional Indonesia juga mengandung segi positip yang lain seperti: Bahan-bahan yang alami, bergizi tinggi, sehat dan aman, murah dan mudah didapat, sesuai dengan selera masyarakat sehingga diyakini punya potensi yang baik sebagai makanan. [14]

Sistem pakar adalah sistem yang berusaha mengadopsi pengetahuan manusia ke komputer yang dirancang untuk memodelkan kemampuan menyelesaikan masalah seperti layaknya seorang pakar. [6]
Provinsi Sulawesi Utara terletak di ujung utara Pulau Sulawesi dengan Ibu kota terletak di kota Manado. Provinsi ini di sebelah selatan berbatasan dengan provinsi Gorontalo yang merupakan hasil pemekaran wilayah dari provinsi Sulawesi Utara. [11]

Aplikasi mengenai sistem pakar juga pernah dibuat oleh peneliti lain [3] dimana secara sistem memiliki kemiripan dalam pengembangannya yaitu menggunakan tools MIT App Inventor. [9]

Dengan demikian yang menjadi tujuan dalam penelitian ini yaitu untuk merancang bangun sistem informasi perangkat lunak penentu kesehatan makanan khas Sulawesi Utara berbasis android.

\section{DASAR TEORI}

\section{A. Sistem Pakar}

Sistem pakar merupakan suatu program komputer yang mengandung pengetahuan dari satu atau lebih pakar manusia mengenai suatu bidang spesifik. Jenis program ini pertama kali dikembangkan oleh periset kecerdasan buatan pada dasawarsa 1960-an dan 1970-an dan diterapkan secara komersial selama 1980-an. Bentuk umum sistem pakar adalah suatu program yang dibuat berdasarkan suatu set aturan yang menganalisis informasi (biasanya diberikan oleh pengguna suatu sistem) mengenai suatu kelas masalah spesifik serta analisis matematis dari masalah tersebut. Tergantung dari desainnya, sistem pakar juga mampu merekomendasikan suatu rangkaian tindakan pengguna untuk dapat menerapkan koreksi.Sistem ini memanfaatkan kapabilitas penalaran untuk mencapai suatu simpulan. [4]

\section{B. Arsitektur Sistem Pakar}

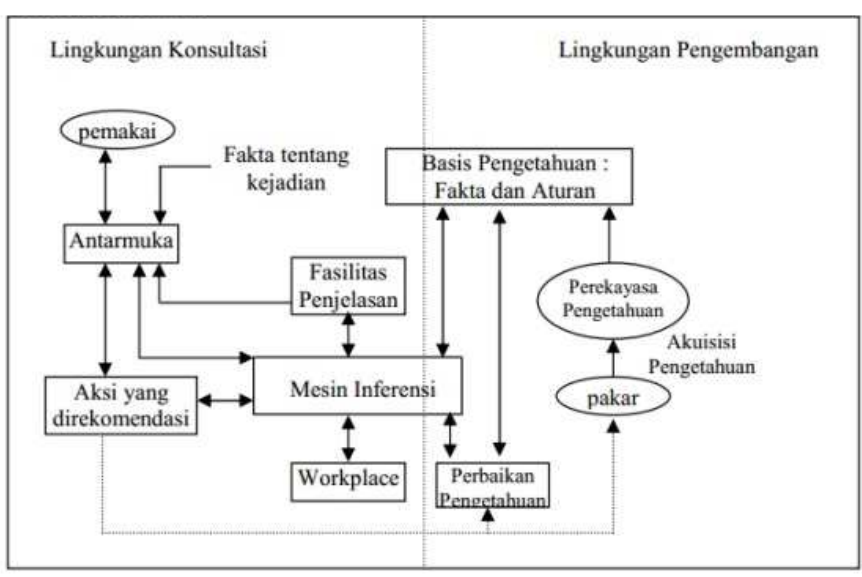

Gambar 1. Arsitektur Sistem Pakar (Turban, 1995) 
Sistem pakar terdiri dari dua bagian pokok, yaitu : lingkungan pengembangan (development environment) dan lingkungan konsultasi (consultation environment). Lingkungan pengembangan digunakan sebagai pembangun sistem pakar baik dari segi pembangun komponen maupun basis pengetahuan.Lingkungan konsultasi digunakan oleh seseorang yang bukan ahli untuk berkonsultasi. [6]

\section{Metode Forward Chaining}

Merupakan cara pelacakan pengetahuan yang dimulai dari fakta awal menuju ke kesimpulan. Pada metode forward chaining di artikan sebagai pendekatan yang dimotori data. Dalam pendekatan ini pelacakan dimulai dari informasi masukan, dan selanjutnya mencoba menggambarkan kesimpulan.Sehingga metode ini juga sering disebut "Data driven”. [6]

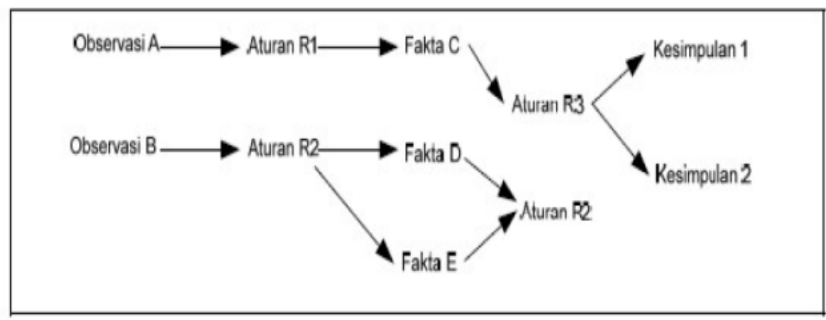

Gambar 2. Metode Forward Chaining

\section{Metode Backward Chaining}

Merupakan cara pelacakan yang dimotori tujuan "goal driven". Strategi ini dimulai dari mode tujuan dan bergerak ke belakang menuju keadaan awal, dalam penalaran ke belakang prosesnya disebut terarah, dimulai dari ekspektasi apa yang diinginkan terjadi (hipotesis), kemudian mengecek pada sebab-sebab yang mendukung (ataupun kontadiktif) dari ekspektasi tersebut. [6]

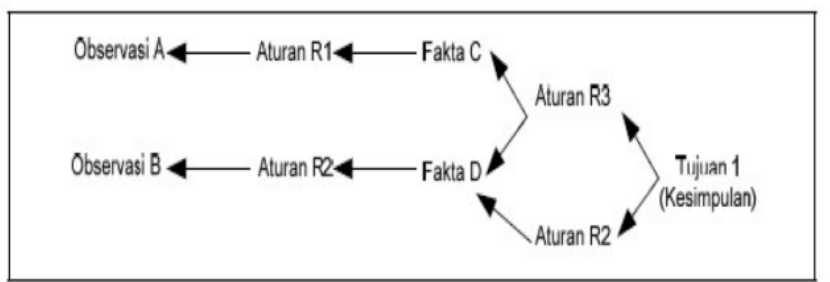

Gambar 3. Metode Backward Chaining

\section{E. Metodologi RAD}

Rapid Application Developmentmenurut Pressman R.S (1997:42) adalah sebuah model proses perkembangan software sekuensial linier yang menekankan siklus perkembangan yang sangat pendek. RAD menurut Bentley \& Whitten (2010) adalah strategi pengembangan sistem yang mana menekankan kecepatan pengembangan melalui keterlibatan user ekstensif dalam kecepatan, iterative (berulang), dan incremental construction dari serangkaian fungsi dari prototype sebuah sistem yang pada akhirnya akan mengalami perubahan secara bertahap menuju sistem akhir. [5]

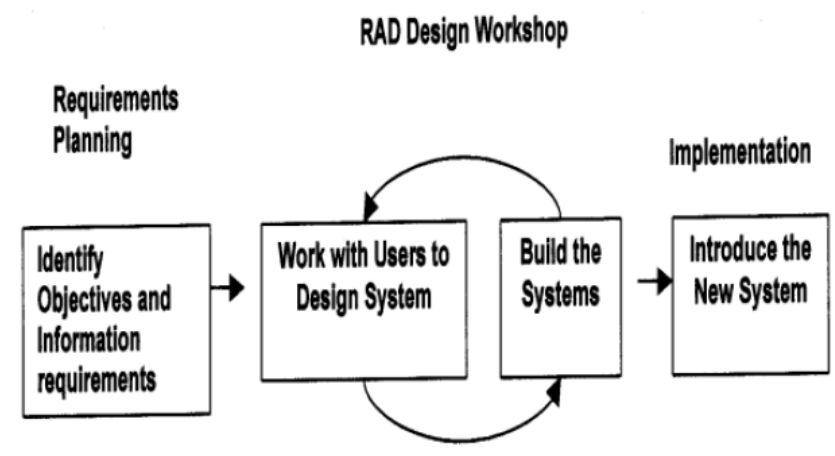

Gambar 4. Tahapan RAD

Ide dasar dari RAD yakni sbb:

1. Untuk lebih aktif lagi mempengaruhi users sistem dalam analisis, design, dan aktifitas konstruksi.

2. Untuk mengatur perkembangan sistem pada rangkaian yang terfokus, workshops yang intens yang secara bersamaan mempengaruhi systemowners, users, analysts, designers, and builders.

3. Untuk mempercepat requirements analysis dan design phase (fase desain) melalui pendekatan konstruksi iteratif.

4. Untuk mengurangi jumlah waktu yang sebelumnya lebih banyak digunakan oleh user untuk mengerti cara kerja sistem.

\section{F. Mit App Inventor}

App Inventor adalah sebuah aplikasi web-based yang disediakan oleh Google dan dikelola oleh Massachusetts Institute ofTechnology (MIT) yang dirilis pada 15 Desember 2010. Pengguna dapat menggunakan tampilan grafis GUI dan tampilan drag and drop visual objek untuk membangun aplikasi berbasis Android.

Dalam penggunaannya App Inventor dimulai melalui webbased service pada web browser secara online (http://beta.appinventor.mit.edu). [9]

\section{G. Rumus Perhitungan Nilai Gizi}

Dengan menggunakan rumus perhitungan nilai gizi, maka didapatkan hasil yang dapat dilihat pada Tabel 1.

$$
\text { Presentasi Bobot Nilai Gizi }=\frac{\text { Nilai Giz (gram) }}{\text { Total Nilai Gizi(gram) }} x 100 \% \ldots \ldots \ldots . .(1)
$$

\section{METODOLOGI PENELITIAN}

\section{A. Komunikasi}

Pada tahap ini, penulis melakukan komunikasi langsung dengan pihak pembuat makanan khas Sulawesi Utara dan ruma makan yang menyediakan makanan khas Sulawesi Utara.Komunikasi yang dilakukan berupa wawancara dengan pembuat makanan khas Sulawesi Utara. Wawancara dilakukan sebanyak satu kali, wawancara dilakukan untuk mengetahui kebutuhan perangkat lunak yang akan dibangun. 


\section{B. Pemodelan}

Pada tahap ini, semua hasil analisa kebutuhan pengguna dan kebutuhan sistem didefinisikan dalam bentuk diagram UML sedangkan interface sistem dimodelkan dengan storyboard

1) Usecase Diagram. Penulis menggunakanusecase diagram untuk mendefinisikan aktivitas-aktivitas pengguna sistem dan interaksi antara pengguna dengan sistem maupun interaksi antar pengguna. Usecase diagram aplikasi sistem pakar penentu kesehatan makanan khas Sulawesi Utara berbasis Android dapat dilihat pada Gambar 5. [1]

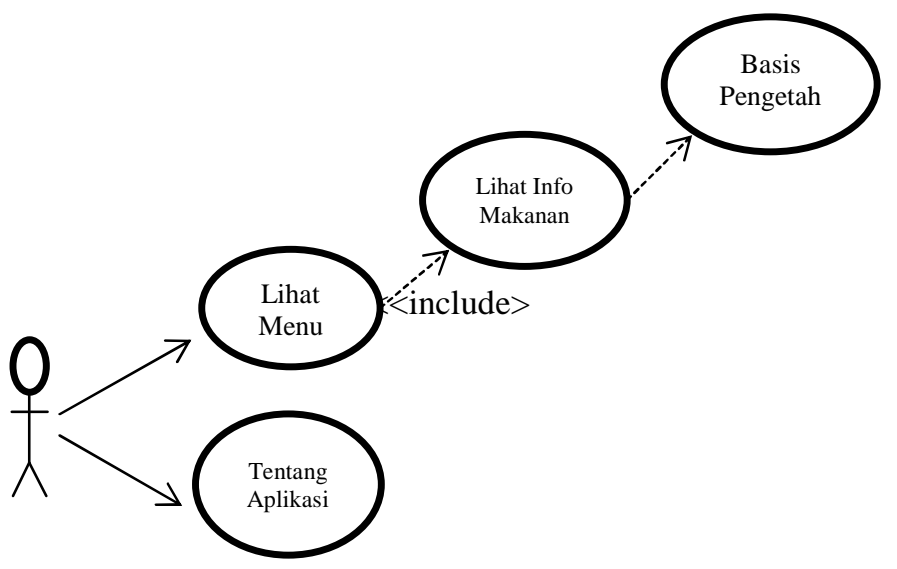

Gambar 5. Usecase Diagram

Pada Use case diagram digambarkan interaksi antara aktor (user)dengan sistem. Di sini digambarkan aktor (user) melakukan beberapa kegiatan seperti meihat menu makanan, mendapatkan informasi makanan dan inforasi gizi makanandan melihat menu "tentang".

2) Flowchart. Langkah ini menghasilkan algoritma pemrograman. Penulis membuat algoritma dalam bentuk flowchart. Pembuatan algoritma ini berfungsi dalam tahap konstruksi, dimana ketika melakukan pemrograman akan didasari pada algoritma-algoritma yang dibuat pada fase ini.

3) Pohon Keputusan Dan Kaidah Produksi. Pohon keputusan merupakan grafik yang akan menjelaskan objekobjek yang dihubungkan dengan gari-garis berlabel ("Ya" atau "Tidak"), alasan digunakan pohon keputusan ini adalah karena lebih mudah dipahami dalam pemecahan masalah. Berikut adalah pohon keputusan sistem pakar penentu makanan khas Suawesi Utara. [6]

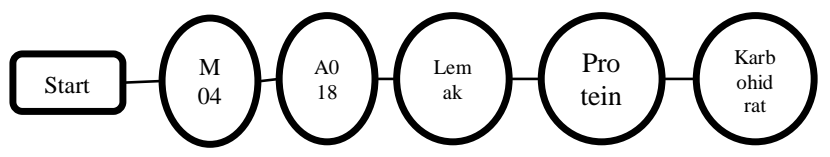

Gambar 6. Pohon Keputusan Ikang Fufu

Pohon keputusan yang ditampilkan sebagai salah contoh pohon keputusan dari lima belas pohon keputusan. Masingmasing makanan mempunyai pohon keputusan.

\section{Klasifikasi Bertingkat}

Klasifikasi bertingkat ini bertujuan untuk mendukung dan menjelaskan pohon keputusan yang telah di buat.Dari klasifikasi bertingkat dapat dilihat dari cabang makanan ke ranting komposisi lanjut ke daun komponen informasi nilai gizi.

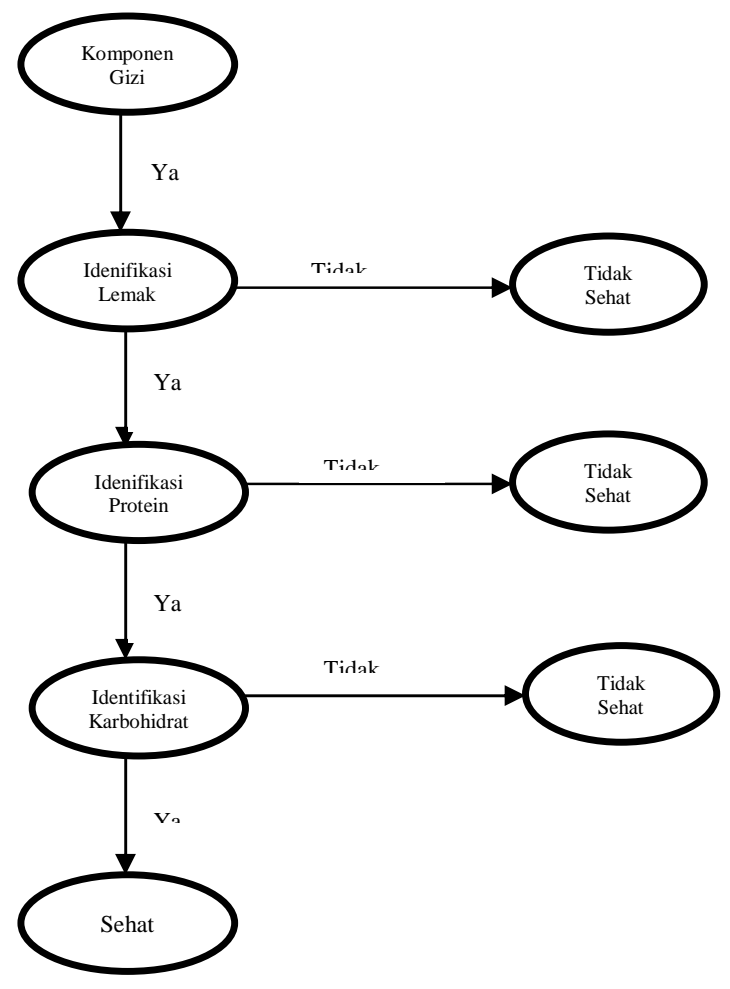

Gambar 7. Klasifikasi Bertingkat

\section{Aturan atau Role}

Pada aturan (Rule), dengan melihat Tabel 2, dapat ditentukan aturan yang digunakan untuk semua makanan khas Sulawesi Utara. [6]

1) IF Lemak $>=24 \%$ AND $<=36 \%$ THEN Sehat, ELSE

Tidak Sehat

2) $\boldsymbol{I F}$ Protein $>=9 \% \boldsymbol{A N D}<=14 \%$ THEN Sehat, $\boldsymbol{E L S E}$

Tidak Sehat

3) IF Karbohidrat $>=54 \%$ AND $<=63 \%$ THEN Sehat, ELSE Tidak Sehat

\section{HASIL}

Setelah menggunakan metodologi RAD dan klasifikasi bertingkat maka didapatkan hasil. Dari hasil tersebut dapat dilihat bahwa beberapa makanan khas Sulawesi Utara mememiliki kelebihan lemak, protein dan karbohidrat seperti pada tabel II.

Oleh karena itu dilakukan dua pengujian yaitu pengujian akurasi dan pengujian halaman aplikasi.

\section{A. Pengujuan Akurasi}

Pengujian akurasi dilakukan untuk megetaui performa sistem dalam menganalisa data yang di input. Data yang diuji berjumlah 15 simple makanan, yakni dengan cara meghitung satu persatu komposisi makanan untuk mendapatkan 
informasi kandungan nilai gizi dimasing-masing makanan dengan menggunakan rumus (1).

Pada tabel presentasi kandungan gizi, akan dilihat presentasi nilai gizi di setiap makanan khas Sulawesi Utara yang dapat dilihat pada tabel II.

Berikut adalah salah satu tabel nutrisi makanan dari lima belas makanan. Dan sebagai contoh tabel tersebut adalah tabel nutrisi makanan Ikang Fufu. [5]

Tabel I. Nutrisi Ikang Fufu

\begin{tabular}{|c|c|c|c|c|c|}
\hline \multirow{2}{*}{ NO } & \multirow{2}{*}{ Nama Bahan } & \multicolumn{4}{|c|}{ Amount } \\
\cline { 3 - 6 } & Protein & Lemak & Karbohidrat & Total \\
\hline \multirow{2}{*}{1} & $\begin{array}{l}\text { Ikang Ckalang }= \\
1,500 \mathrm{~g}\end{array}$ & $277.5 \mathrm{~g}$ & $43.5 \mathrm{~g}$ & $0.0 \mathrm{~g}$ & \\
\hline \multicolumn{2}{|c|}{ Total } & $277.5 \mathrm{~g}$ & $43.5 \mathrm{~g}$ & $0.0 \mathrm{~g}$ & 321 \\
\hline \multicolumn{2}{|c|}{ Total Nilai Gizi } & $86.45 \%$ & $13.55 \%$ & $0 \%$ & $100 \%$ \\
\hline
\end{tabular}

Berdasakan tabel nutrisi, dapat diperoleh nilai akurasi gizi yang dihitung dengan perhitungan presentasi bobot nilai gizi dan ditampilkan pada tabel II.

Berikut ini hasil presentasi komposisi gizi dari protein, karbohidrat dan lemak yang telah dihitung untuk masingmasing sampel makanan beserta tempat rumah makan yang membuat makanan khas Sulawesi Utara. [5]

\begin{tabular}{|c|l|c|c|c|c|}
\multicolumn{5}{|c}{ Tabel II. Presentasi Kandungan Gizi } \\
\hline No & $\begin{array}{c}\text { Nama } \\
\text { Makanan }\end{array}$ & Lemak & Protein & $\begin{array}{c}\text { Karbohid } \\
\text { rat }\end{array}$ & \multicolumn{1}{|c|}{ Info } \\
\hline 1 & Nasi Jaha & $1.37 \%$ & $7.78 \%$ & $90.85 \%$ & $\begin{array}{c}\text { Kelebihan } \\
\text { Karbohidrat }\end{array}$ \\
\hline 2 & Sate Kolombi & $8.85 \%$ & $5.11 \%$ & $86.04 \%$ & $\begin{array}{c}\text { Kelebihan } \\
\text { Karbohidrat }\end{array}$ \\
\hline 3 & Ragey & $40.44 \%$ & $57.43 \%$ & $2.13 \%$ & $\begin{array}{c}\text { Kelebihan } \\
\text { Protein }\end{array}$ \\
\hline 4 & Ikang Fufu & $13.55 \%$ & $86.45 \%$ & $0 \%$ & $\begin{array}{c}\text { Kelebihan } \\
\text { Protein }\end{array}$ \\
\hline 5 & Mie Cakalang & $9.23 \%$ & $23.95 \%$ & $66.82 \%$ & $\begin{array}{c}\text { Kelebihan } \\
\text { Karbohidrat }\end{array}$ \\
\hline 6 & Tinutuan & $3.39 \%$ & $11.53 \%$ & $85.08 \%$ & $\begin{array}{c}\text { Kelebihan } \\
\text { Karbohidrat }\end{array}$ \\
\hline 7 & Paniki & $44.5 \%$ & $13.16 \%$ & $42.34 \%$ & $\begin{array}{c}\text { Kelebihan } \\
\text { Lemak }\end{array}$ \\
\hline 8 & Kawok & $18.17 \%$ & $18.17 \%$ & $63.66 \%$ & $\begin{array}{c}\text { Kelebihan } \\
\text { Protein }\end{array}$ \\
\hline 9 & Patola & $23.14 \%$ & $14.27 \%$ & $62.59 \%$ & $\begin{array}{c}\text { Kelebihan } \\
\text { Karbohidrat }\end{array}$ \\
\hline 10 & Klapatart & $19.71 \%$ & $10.67 \%$ & $69.62 \%$ & $\begin{array}{c}\text { Kelebihan } \\
\text { Karbohidrat }\end{array}$ \\
\hline 12 & Rica Roa & $39.81 \%$ & $15.72 \%$ & $44.47 \%$ & $\begin{array}{c}\text { Kelebihan } \\
\text { Lemak }\end{array}$ \\
\hline 13 & Tinorangsak & $36.31 \%$ & $42.68 \%$ & $21.01 \%$ & $\begin{array}{c}\text { Kelebihan } \\
\text { Protein }\end{array}$ \\
\hline Woku & $30.28 \%$ & $57 \%$ & $12.72 \%$ & $\begin{array}{c}\text { Kelebihan } \\
\text { Protein }\end{array}$ \\
\hline
\end{tabular}

\begin{tabular}{|l|l|l|l|l|l|}
\hline 15 & Saut & $27.63 \%$ & $45 \%$ & $27.37 \%$ & $\begin{array}{c}\text { Kelebihan } \\
\text { Protein }\end{array}$ \\
\hline
\end{tabular}

Berdasarkan perhitungan pada Tabel 3, dapat disimpulkan bahwa nasi jaha, sate kolombi, mie cakalang, tinutuan, patola dan klapatart adalah makanan yang karbohidratnya berlebihan. Untuk makanan ragey, ikang fufu, paniki, kawok, rw, tinorangsak, woku dan saut adalah makanan yang mempunyai kelebihan protein, untuk makanan paniki dan rica roa adalah makanan yang mempunyai kelebihan di lemak.

Pada saat selesai melakukan semua tahapan dengan metodologi yang digunakan, maka pada tahap ini akan dijelaskan hasil dari perancangan yang dilakukan berdasarkan tujuan awal yaitu membuat suatu aplikasi sistem pakakr penentu kesehatan makanan khas Sulawesi Utara berbasis Android. [5]

\section{B. Halaman Aplikasi}

Berikut ini adalah interface dari aplikasi sistem pakar penentu kesehatan makanan khas Sulawesi Utara berbasis Android. Tampilan ini merupakan tampilan awal dari sistem, yang di dalamnya tersedia button menu, button Tentang dan button keluar. Tampilanya seperti pada gambar 8 .

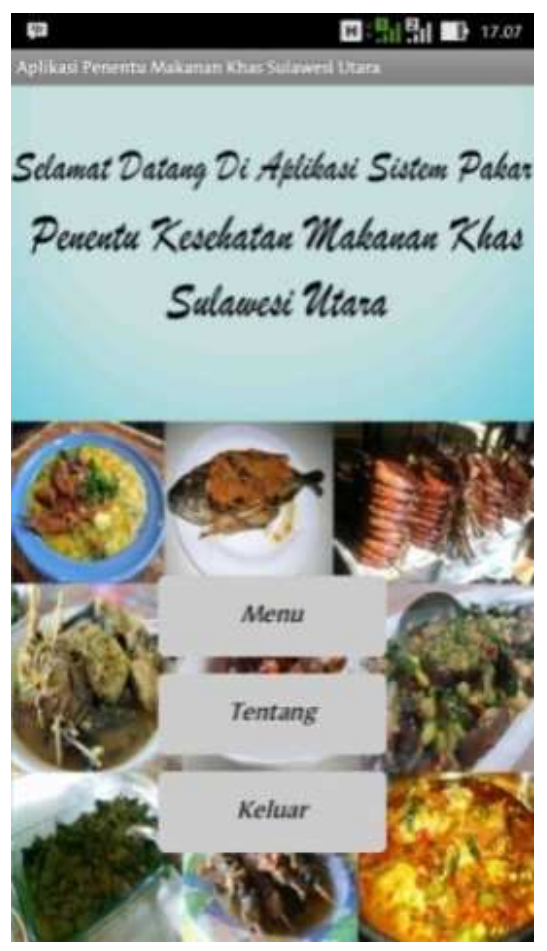

Gambar 8. Halaman awal Aplikasi

\section{Tampilan Menu}

Saat memilih button menu, pada tampilan menu terdapat lima belas makanan khas Sulawesi Utara yang dapat dilihat informasinya berupa informasi kesehatan makanan, komposisi makanan dan saran kesehatan. Tampilanya seperti pada gambar 9. 


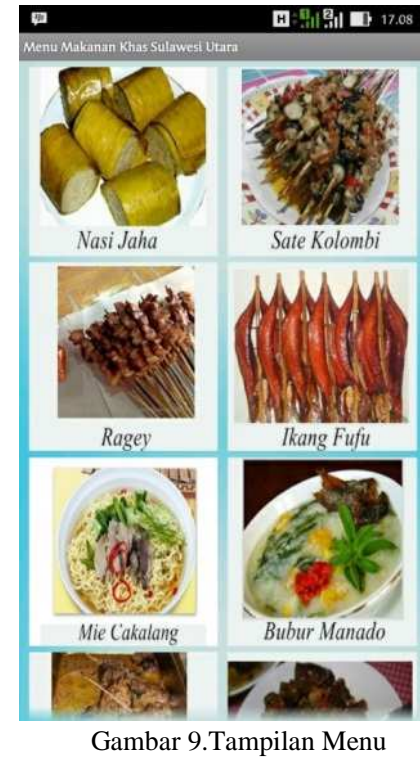

Pada saat memilih makanan yang terdapat didaftar menu pada gambar 9. Maka selanjutnya kita akan mendapatkan informasi komposisi makanan dan nilai gizi makanan. Tampilanya seperti pada gambar 10 .

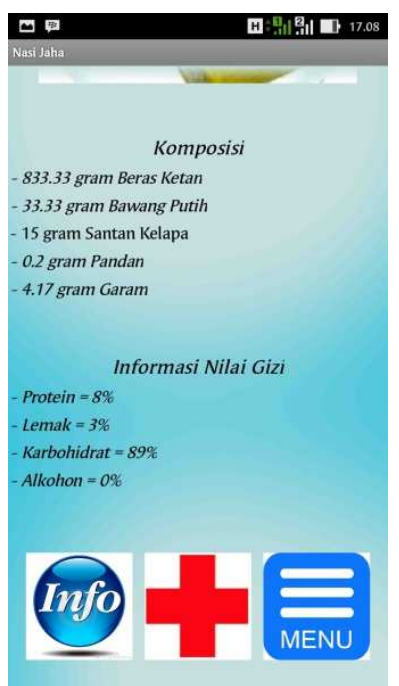

Gambar 10. Tampilan Informasi Komposisi dan Informasi Nilai Gizi Nasi Jaha

Dapat dilihat pada gambar 11 yaitu Tampilan Informasi Komposisi dan Informasi Nilai Gizi terdapat informasi berupa komposisi untuk makanan nasi yaha yang kandungan komposisinya 833.33 gram beras ketan, 33,33 gram bawang putih, 15 gram santan kelapa, 0.2 gram pandan dan 4,17 gram gara. Selain itu terdapat Informasi Nilai Gizi yang mengandung protein sebanyak $8 \%$, lemak sebanyak $3 \%$ karbohidrat sebanyak 38\% dan alcohol $0 \%$.

Dari presentasi kandungan nilai gizi tersebut, dapat dilihat bahwa makanan nasi jaha mengandung kelebihan karbohirdrat. Jika dikonsumsi secara berlebihan makanan yang mengandung kelebihan karbohidrat maka penyakit yang akan ditimbulkan diantaranya diabetes tipe 2, penumpukan karies gigi, penyakit jantung, produksi lemak berlebihan, sindrom metabolism dll.

Selanjutnya merupakan tampilan informasi makanan ragey, pada tampilan ini terdapat informasi komposisi dan informasi nilai gizi. Pada infromasi komposisi terdapat 250 gram daging babi, 0,8 gram jeruk nipis, 5 gam sereh, 0,4 gram garam, 1 gram gram vetsin, 0,27 gram asam cuka, 4 gram jahe. Dan informasi nilai gizi terdapat presentasi lemak $40,44 \%$, protein $57,43 \%$ dan karbohidrat $2,13 \%$ seperti pada gambar 11.

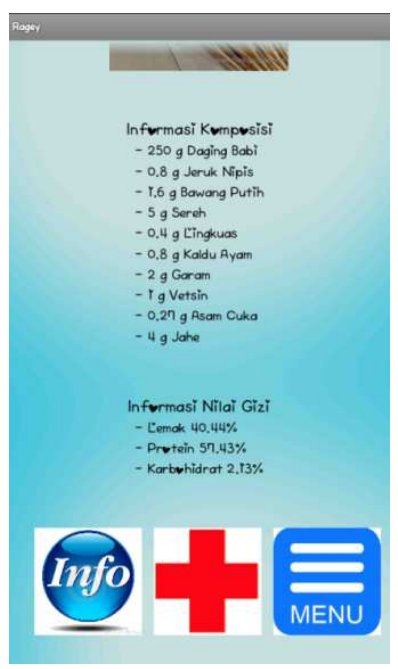

Gambar 11. Tampilan Informasi Komposisi dan Informasi Nilai Gizi Ragey

Dari gambar diatas dapat disimpulkan bahwa makanan ragey mempunyai kelebihan di lemak. Makanan yang mempunyai kelebihan lemak jika dikonsumsi secara berlebihan maka penyakit yang akan ditimbulkan adalah obesitas, kerusakan dinding arteri, meingkatkan resiko kanker, sembelit, kerusakan otak dan kolestrol tinggi.

Setelah dilakukan beberapa pengujian dibeberapa orang secara acak, didapkan hasil bahwa Aplikasi Sistem Pakar Penentu Kesehatan Makanan Khas Sulawesi Utara mampu membantu dalam mendaptakn informasi kesehatan makanan khas Sulawesi Utara seperti pada tabel III.

Tabel III. Uji Coba Aplikasi

\begin{tabular}{|c|l|c|lr|}
\hline NO & Nama & Umur & Komentar & Mendapatkan \\
\hline 1. & User 1 & 25 & $\begin{array}{l}\text { Membantu } \\
\text { Informasi }\end{array}$ & Mendapatkan \\
\hline 2. & User 2 & 22 & $\begin{array}{l}\text { Lebih Mudah } \\
\text { Informasi Kesehatan Makanan } \\
\text { Khas }\end{array}$ \\
\hline 3. & User 3 & 24 & $\begin{array}{l}\text { Berguna dalam mendapatkan } \\
\text { informasi dan } \\
\text { makanan. }\end{array}$ \\
\hline
\end{tabular}

\section{PENUTUP}

\section{A. Kesimpulan}

Berdasarkan hasil pengujian dan implementasi aplikasi sistem pakar penentu kesehatan makanan Khas Sulawesi Utara berbasis android, dapat disimpulkan sebagai berikut:

1) Aplikasi sistem pakar penentu kesehatan makanan khas Sulawesi Utara dapat berjalan dengan baik sesuai rancangan. Aplikasi mampu membantu pengguna aplikasi dalam memperoleh informasi makanan baik komposisi dan informasi nilai gizi maupun saran kesehatan. 
2) Dengan adanya sistem pakar ini maka dapat membantu efisiensi waktu dalam memperoleh informasi kesehatan makanan khas Sulawesi Utara serta meminimalisir biaya untuk mencari informasi ke ahli gizi

3) Dengan menggunakan klasifikasi bertingkat mampu membantu menyelesaikan dalam menentukan makanan sehat dan tidak sehat.

\section{B. Saran}

Untuk penelitian selanjutnya agar melakukan perbaikan pengetahuan, untuk meningkatkan nilai ke akuratan sistem pakar.

\section{DAFTAR PUSTAKA}

[1] Fowler, Martin, 2005. UML Distilled Edisi 3, Andi. Yogyakarta.

[2] Hardiyansyah, Riyadi Hadi dan Napitipulu Victor, 2012. Kecukupan Energi, Protein, Lemak dan Karbohidrat. Tesis Departemen Gizi Masyarakat FEMA IPB Departemen Gizi. Universitas Indonesia. Jakarta.

[3] Kaburuan Yonna G, Sentinuwo Steven R., Manembu Pinrolinvic D. K. 2015. Rencana Bangun Aplikasi Uji Kepribadian MBTI Berbasis Android Menggunakan Sistem Pakar. Skripsi Program Studi S1 Teknik Elektro Jurusan Informatika Universitas Sam Ratulangi. Manado.

[4] Nugroho Bunafit. 2014. Aplikasi Sistem Pakar dengan PHP dan Editor Dreamweaver. Gava Media. Jogjakarta

[5] Preesman, Roger S. 2010. Software Engineering : A Practitioner's Approach, Seventh Edition. Mc Graw Hill Higher Education.

[6] Turban, E. (1995). Decision Support and Expert System; Management Support System. Newyork: Prentice-Hall.

[7] Center of Reliable Health Information, 6 Akibat kelebihan Lemak dalam Tubuh. http://halosehat.com/gizi-nutrisi/panduangizi/akibat-kelebihan-lemak, 11 Oktober 2015

[8] Center of Reliable Health Information, 11 Akibat Kelebihan Karbohidrat dalam Tubuh. http://halosehat.com/gizi-nutrisi/panduan-gizi/akibat-kelebihankarbohidrat,

11 Oktober 2015

[9] MIT App Inventor, Getting Started With App Inventor. http://appinventor.mit.edu/explore/get-started.html, 1 Februari 2016.

[10] Scott W. Ambler 2010, Disciplined Agile Delivery (DAD) Lifecycles.

https://www.ibm.com/developerworks/community/blogs/ambler /entry/disciplined_agile_delivery_dad_lifecycle14,

29 September 2015.

[11] Sektioko. Bambang, Resep Sambal Roa Mando. http://www.cararesep.com/resep-sambal-roa-manado.html, 28 September 2015.
[12] Tm Cetak, Reporter, Ular Patola Bumbu Rica-rica Sembuhkan Asma. http://manado.tribunnews.com/2014/08/31/ular-patola-bumburica-rica-sembuhkan-asma, 28 September 2015.

[13] Wolajan. Finnike, Rahasia Nikmatnya Ragey Om Wagey Minahasa. http://manado.tribunnews.com/2014/08/16/rahasia-nikmatnyaragey-om-wagey-minahasa, 28 September 2015.

[14] Wisata Kuliner, Makanan Khas Sulawesi Utara. http://www.seputarsulut.com/makanan-khas-sulawesi-utara/. 11 Februari 2015.

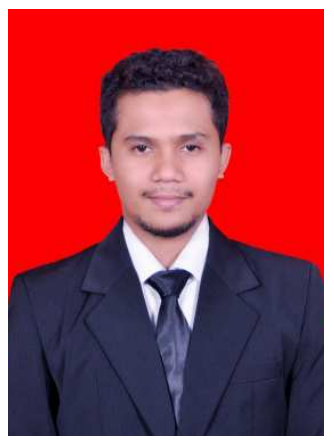

Penulis bernama lengkap Muhammad Iqbal Kaplale, anak kedua dari empat orang bersaudara. Lahir di Galela, pada tanggal 10 Oktober 1991. Dengan alamat tempat tinggal sekarang Malalayang I, Jl. Mogandi 10.Sekolah pertama tempat belajar adalah Taman Kanak-kanak Dharma Wanita Soa SioGalela.Selanjutnta, melanjutkan ke SD INPRES Soa Sio Galela. Setelah itu, melanjutkan keSMP Negeri 2 Galela. Dan menyelesaikan sekolah tingkat atas di SMA Negeri 1 Galela.

Pada tahun 2010, Penulis melanjutkan studi di Fakultas Teknik, Jurusan Elektro, Program Studi Informatika Universitas Sam Ratulangi Manado.Selama kuliah, Penulis tergabung dalam organisasi Himpunan Mahasiswa Elektro (HME) dan Badan Tazkir Fakultas Teknik UNSRAT. 